\title{
Deep Structure of the North Caspian Basin
}

\author{
by A.E. Shlezinger
}

The North Caspian depression is currently one of the most exciting targets for oil and gas exploration in the Soviet Union. Regarded as one of the world's deepest sedimentary basins, it had a lengthy history of sedimentation from the Late Precambrian to the Cenozoic. Prominent in the sedimentary pile, which ranges up to $23 \mathrm{~km}$ thick, are widespread deep-water salt deposits of Lower Permian age, subsequently redistributed by extensive salt tectonics. As the author reports here, recent seismic work has revealed many details of the Phanerozoic "complexes," as well as indicating firmly that the central part of the basin is underlain by oceanic crust. The absence of Phanerozoic orogenic structures recalls earlier suggestions that the North Caspian basin may be underlain by some of the least disturbed ancient oceanic crust to be found anywhere.

\section{Geology of the North Caspian Basin}

The North Caspian depression or syneclise (also known as the Pri-caspian, Cis-Caspian or Fore-Caspian) lies to the north of the Caspian Sea, where it occupies a vast lowland area covering more than $500,000 \mathrm{~km}^{2}$ (Fig. 1). The Geological Map of the USSR $(1983,1: 2,500,000)$ shows the complex surface geology of the basin, much of which is clearly linked to salt-dome tectonies (see also Peive et al., 1981 - Ed.). East of the Ural River, the basin is characterized by innumerable open, irregularly elongated anticlines and synclines involving mainly Jurassic and Cretaceous rocks. The northwestern quadrant, west of the Ural River, likewise exhibits many domes, with Kungurian to Jurassic cores surrounded by Eocene rocks. The western and southwestern parts of the basin are composed of Upper Pliocene to Quaternary sediments, whereas to the southeast and east are arcuate areas of Eocene and Oligocene to Miocene. In the northeast the map shows a complex pattern of folded and faulted Palaeozoic and Mesozoic rocks where the basin adjoins the southernmost Urals. (Ed.)

The basin is composed of three supracrustal rock "packages": a Proterozoic to Lower Permian sub-salt complex overlain by a thick salt-dome complex of Permian saliferous sediments covered in turn by Upper Permian to Cenozoic strata (the cover complex), for a total thickness of up to $23 \mathrm{~km}$. Geophysical data (some obtained from deep seismic profiles using underground nuclear explosions, according to Scheimer and Borg, 1984 - Ed.) indicate that these complexes were deposited on Archaean to Lower Proterozoic metamorphics, which themselves rest on a thinned crust. In central parts of the basin, the latter is presumed to be of oceanic origin from its seismic velocities of 7.2-7.5 km/sec (Abdulin et al., 1984; Kunin, Ioganson and Bylevskiy, $1980-E d$.). The metamorphic basement occurs at depths of $7-15 \mathrm{~km}$ on the sides of the basin, descending across step-like features to depths of 20-23 $\mathrm{km}$ in the central basin (see figures 3 and 4 in Scheimer and Borg, $1984-E d$.).
At the base of the supracrustal sequence are Riphean (Proterozoic) to Lower Permian (pre-Kungurian) sediments varying in thickness from $3-4 \mathrm{~km}$ in some marginal areas to $10-15 \mathrm{~km}$ in the center of the basin. These are covered by 6 to $8 \mathrm{~km}$ of salt-bearing Kungurian rocks characterized by diapiric structures, some of which in the central part of the basin may be as much as $10 \mathrm{~km}$ in height. The salt domes and ridges vary greatly in size from 20 to $2,300 \mathrm{~km}^{2}$. Some are exposed on the surface, in places forming hills to $150 \mathrm{~m}$ high, whereas others reach to within $100 \mathrm{~m}$ of the surface in the eastern, central and northern portions, and $2000 \mathrm{~m}$ in the south and southeast (Peive et al., 1981; Abdulin et al., 1984 Ed.). In the zones between the diapirs, the Kungurian deposits are almost completely dislocated as a result of the diapiric motions.

The Kungurian is overlain by up to $3500 \mathrm{~m}$ of Upper Permian and Triassic terrigenous sediments, which accumulated as salt domes were forming. They are succeeded in turn by up to $2500 \mathrm{~m}$ of Lower Jurassic to Paleogene terrigenous and carbonate sediments. In the western part of the basin the latter are unconformably overlain by flat Upper Pliocene to Quaternary clays, sands, silts and minor limestones, which form a thin $(<300 \mathrm{~m})$ mantle, except in active "compensational" troughs where they may be up to $1.5-2 \mathrm{~km}$ thick.

\section{Current Models for the Structure of the Basin}

There are two main ideas on the deep-seated structure of the North Caspian depression, each suggesting different approaches to the evaluation of its mineral resources. The

Figure 1: Regional setting of the North Caspian basin (modified from Meyerhoff, 1980).

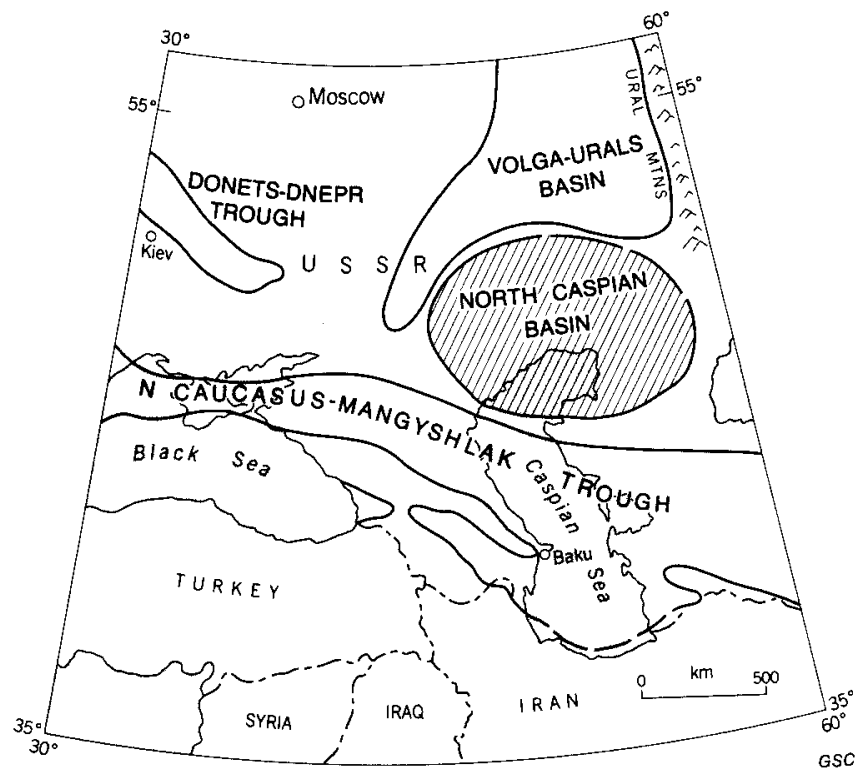




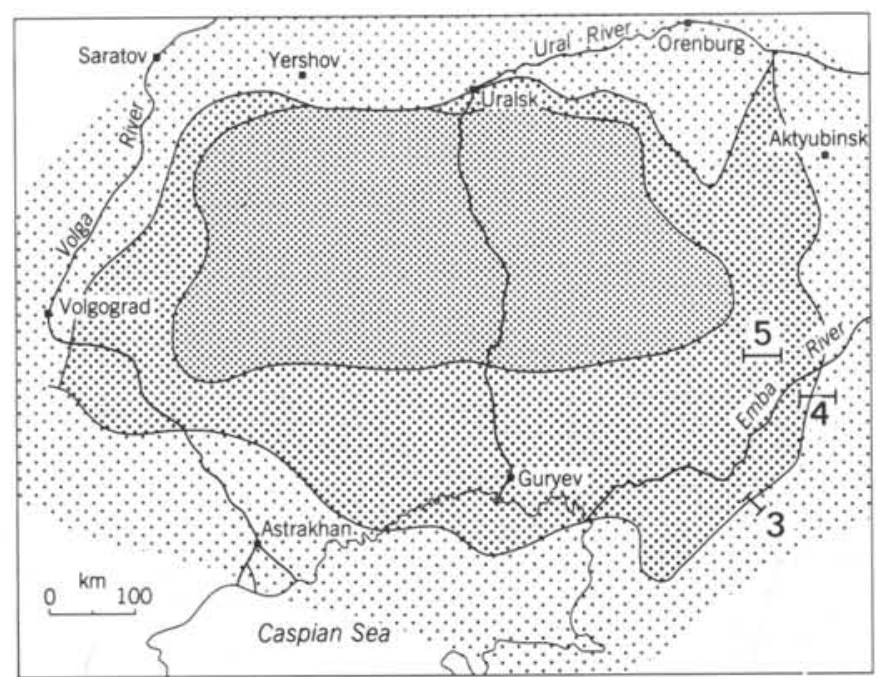

Zones of distinct seismic velocity

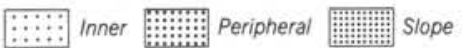

Figure 2: Broad zoning of the North Caspian basin based on the rate of seismic wave propagation.

first view is based on comparisons with other depressions and regards the North Caspian basin as a structure of the East European Platform, with the sub-salt Palaeozoic rocks interpreted according to known sections in relatively uplifted portions of the basin. This long-held approach is currently supported by many researchers who apply it both to the whole of the North Caspian depression and to some of its constituent parts (Abramov, 1977; Alekseyev, Gottikh and Yarikov, 1976; Dzhumagaliev et al., 1981; Kalinin et al., 1982; Latskova, 1977; Movshovich, 1976; Shafiro, 1980; Shafiro, Zolotukhina and Ketat, 1978).

However, in 1961, M.M. Grachevsky became the first to predict that the deep-seated parts of the North Caspian depression differ markedly in structure from the surrounding
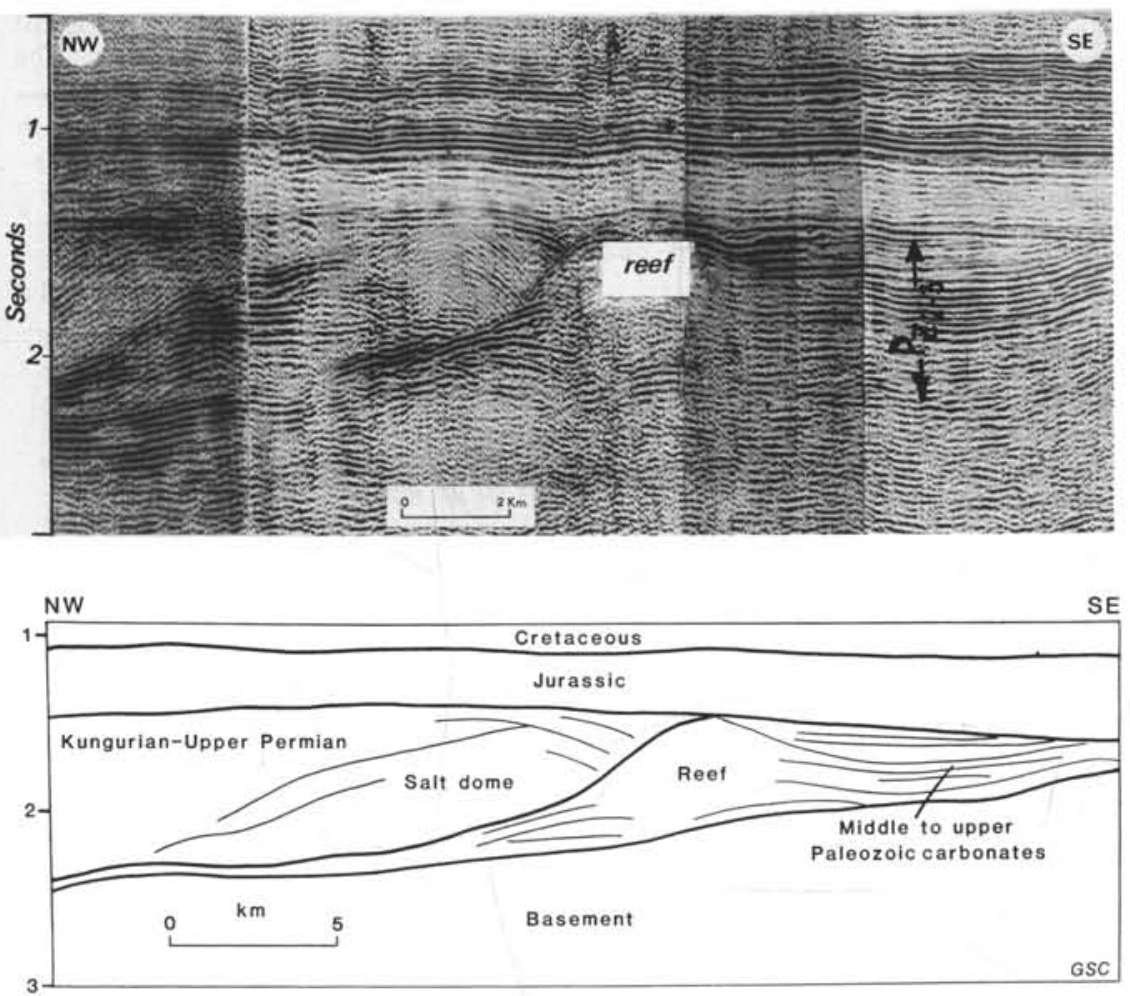

areas of the East European Platform. He singled out a carbonate slope scarp and suggested that this was followed by synchronous, relatively thin deposits of deep-water (depression) facies. Yanshin and Garetsky (1960) had earlier proved the deep-water nature of the Kungurian salt sequences. The seismic and drilling investigations that followed supported this interpretation (Bush et al., 1968; Khatyanov, 1976; Kiryukhin et al., 1978; 1980, 1981; Mirchink, Shakhnovsky and Shebaldin, 1973; Yanshin et al., 1977, 1978, 1979, 1980).

\section{Regional Seismic Structure}

The North Caspian depression has three distinct zones characterized by different seismic propagation rates (Fig. 2). The outer, slope zone and its fringes are characterized by a high velocity refractory wave $\left(\mathrm{P}_{O C} 4\right)$ and a specific group of high velocity reflections. The intermediate, peripheral zone, in contrast, registers no high velocity refractory wave. However there appears to be here a group of relatively low velocity reflections with a time interval of 1.0-1.5 sec, bounded below by the Precambrian crystalline basement. Finally, the inner zone is characterized by a pronounced high velocity wave $\left(\mathrm{P}_{\mathrm{OC}}{ }^{5}\right)$, which is registered below the reflecting horizon. At the level of this wave and below, four to five continuous reflections are recorded with 2 to 3 second intervals.

\section{Structure of the Sub-salt Sequence}

Within the slope zone (Fig. 2), the North Caspian depression is encircled at depth by uplifted, gently dipping preKungurian rocks, which within the basin vary sharply in composition and thickness. Northeast of the basin are thick (to 2-3 km) earbonate complexes of Upper Devonian-Lower Permian age. Common-depth-point sections, supported by drilling, indicate that these complexes wedge out sharply southwards to be replaced by carbonate clays, which form three buried east-west scarps (see Fig. 3 ). The sub-salt floor thus descends in steps from north to south.

The southwestern slope of the North Caspian basin remains its least studied part. Pre-Kungurian terrigenous sediments may dominate here, dipping towards the basin, but the carbonate scarps have not been detected. To the east, Upper Devonian to Middle Carboniferous carbonates appear again to form the large Astrakhan upland. According to seismic data, their thickness ranges from 2.5 to $3 \mathrm{~km}$. The carbonates here underlie thin terrigenous deposits of the preKungurian Lower Permian, comprising the lower molasse of the Karakul foredeep.

The same carbonates extend under the Caspian Sea to its eastern coast, where they range in thickness up to $2.5-3.0 \mathrm{~km}$. Isolated equidimensional swells of probable Middle Carboniferous to Lower Permian carbonates occur here with a total thickness of $600-700 \mathrm{~m}$. The sub-salt section of the Palaeozoic is here crowned by relatively thin (to $120 \mathrm{~m}$ ) clays and fine-grained terrigenous deposits of the pre-Kungurian Lower Permian.

The carbonates of the eastern Caspian coast bend northeast around the rim of the basin. To the northwest, Upper Visean-Sakmarian

Figure 3: Seismic section across the southeastern slope of the North

4 Caspian basin, showing the transition in the midale-upper Palaeozoic from carbonates to thin clay-carbonate deposits of the deep-water (depression) facies. Reef and dome structures are clearly seen. See Figure 2 for location. 


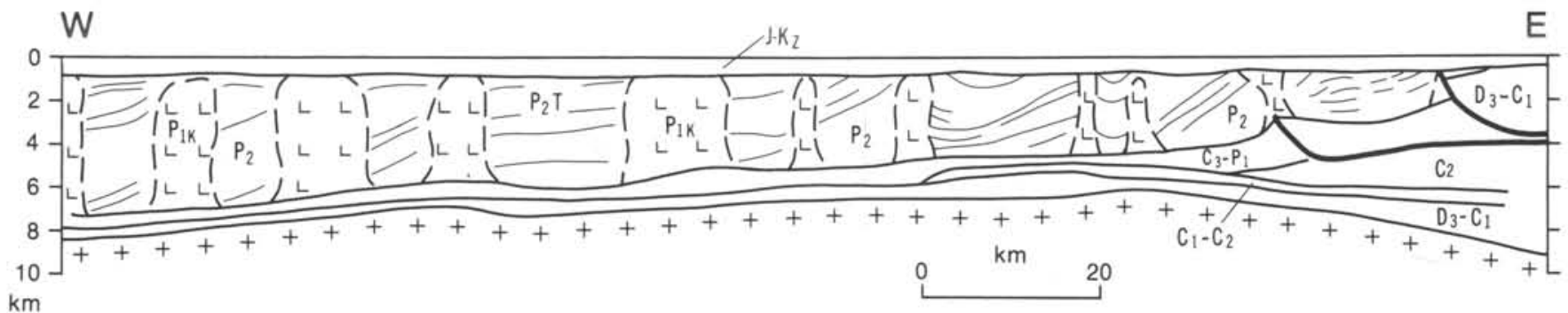

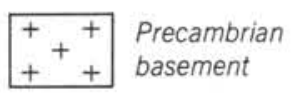

$\begin{array}{ll}\mathrm{JK}_{2} & \text { Jurassic to Cenozoic } \\ \mathrm{T} & \text { Triassic }\end{array}$

$\mathrm{P}_{2}$ Upper Permian

$P_{1 k}$ Kungurian

$\mathrm{P}_{1}$ Lower Permian (pre-Kungurian)
Seismic boundary and reflector.

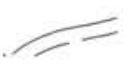

Fault

D3 Upper Devonian

$\begin{array}{ll}\mathrm{C}_{3} & \text { Upper Carboniferous } \\ \mathrm{C}_{2} & \text { Middle Carboniferous } \\ \mathrm{C}_{1} & \text { Lower Carboniferous }\end{array}$

GSC
Figure 4: Geological section from the eastern slope to the peripheral zones of the basin - see Figure 2 for location.

carbonates thin out sharply to form a linear wedge, which gives way to relatively thin, deep-water deposits of the "depression facies" (Fig. 3). The upper surface of this wedge dips more steeply than the lower, so that the top of the wedge forms a scarp. In the southeast, this has a relatively gentle slope $\left(10^{\circ}\right.$ or less) with a height of up to $1 \mathrm{~km}$ and a width of up to $2.0-2.5 \mathrm{~km}$. To the northeast the scarp slope becomes steeper (to $30^{\circ}-35^{\circ}$ ).

The $2 \mathrm{~km}$-thick carbonate complex of the eastern slope zone of the basin (Fig. 4) ranges from Upper Visean to Moscovian in age (Kukhtinov et al., 1981). It is divided by a Lower Moscovian grey terrigenous rock unit $500 \mathrm{~m}$ thick, which separates the carbonate scarp into two parts. Above the carbonate complex here is a thick (to $3-4 \mathrm{~km}$ ) series of grey terrigenous deposits of Upper Carboniferous to preKungurian. These sediments fill in the Ostansuk and Atzhaksin troughs adjacent to the Urals, and become gradually thinner westward, pinching out completely in some places. Near the scarps they reappear, lying on the surface of the carbonates. The lower (pre-Upper Visean) terrigenous part of the sub-salt sequence in the southeastern and eastern basin decreases steadily in thickness to the west and northwest from $3-4 \mathrm{~km}$ to less than $1 \mathrm{~km}$.

In the peripheral zone of the North Caspian basin, the sub-salt unit has a different character. In the east and south, this zone coincides with a broad marginal upland of Precambrian basement (the Aktyubinsk-Primorie system). The peripheral zone is here some $350-400 \mathrm{~km}$ wide, but is reduced to $100 \mathrm{~km}$ in the northwest and west. No high-velocity carbonate complexes have been detected, and the sub-salt unit is no more than $2-3 \mathrm{~km}$ thick (Fig. 4). It is composed of terrigenous deposits of Devonian to Lower Carboniferous and Middle Carboniferous to pre-Kungurian. Seismic reflectors here are gently dipping and almost parallel to the top of the Precambrian basement, which slopes regionally towards the inner zone of the basin (Fig. 5).

The inner zone of the basin is characterized by the increasing inwards slope of its basement, which goes down to a maximum depth of $20-23 \mathrm{~km}$. The Middle-Upper Palaeozoic sub-salt layers, however, remain gently sloping and are similar in composition and mode of occurrence to their counterparts in the peripheral zone. Towards the center, they become thinner (to $1-2 \mathrm{~km}$ ), then thicker (to $2-4 \mathrm{~km}$ ) due to the presence of a more substantial accumulation of Upper Devonian rocks. In the center of the inner zone there is evidence of a new, thick (to $10 \mathrm{~km}$ ) Riphean to Lower Palaeozoic complex underlying the Middle to Upper Palaeozoic rocks. Seismic sections show that the older complex here is composed of gently sloping carbonate and terrigenous rock sequences that fill a deep, generally equant (though slightly elongated from east to west), central depression. At the margins of this depression, the Riphean to Lower Palaeozoic layers rest discordantly on the basement surface.

\section{The Geology of Units Below the Salt}

The North Caspian basin contains a wide range of sedimentary and structural units. As shown above, the shallow carbonate complexes of the slope zone and its fringes wedge out towards the basin where their place is taken by the relatively thin deep-water deposits of the "depression complex." The tops of the wedges form carbonate escarpments. The overlying terrigenous deposits increase sharply in thickness towards the basin forming parallel-sided strata of the "infilling complex" (talus facies - Ed.). In the peripheral zone, the pre-Kungurian strata comprise mainly shallow-

Figure 5: A short seismic profile across the eastern peripheral zone showing relatively thin, gently sloping layers (P1, P2, P3) in the sub-salt sequences. The multiple reflectors labelled $P P$ are regarded as close to the surface of the Precambrian basement. See Figure 2 for location.

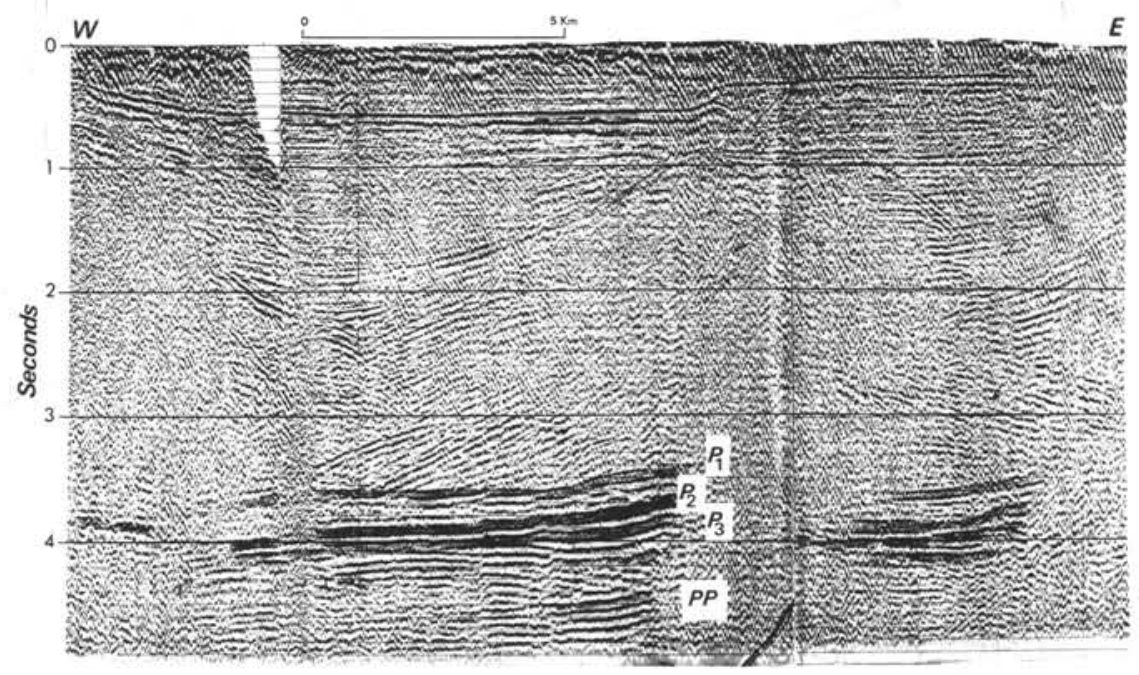




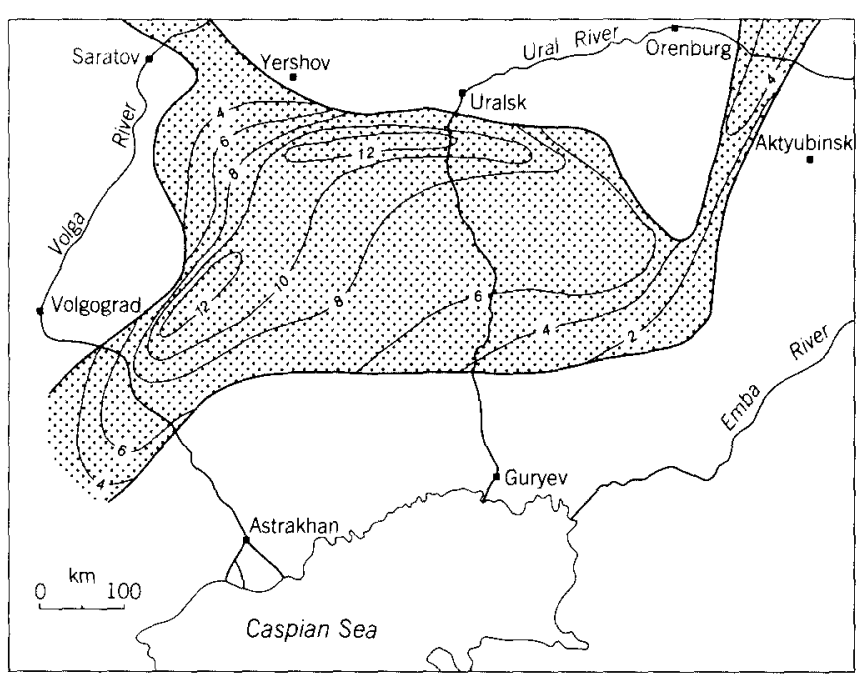

Figure 6: Distribution of Riphean to lower Palaeozoic rocks in the North Caspian basin, showing isopachs in $\mathrm{km}$.

water, terrigenous complexes whose thickness varies according to the amount of subsidence that took place during deposition.

The overall structure of the Riphean-Lower Palaeozoic rock complex resting on the Precambrian basement, remains largely enigmatic as far as the inner Caspian zone is concerned. However, the great and broadly varying thickness of the layers along the slopes of the depression suggest that they represent infillings of a deep-water basin ( $\mathrm{Fig} .6$ ).

There are few data on the pre-Upper Frasnian terrigenous deposits of the northern and western slopes of the basin, but there is evidence of Silurian deposits that increase slightly inwards in thickness. In contrast, in the eastern part of the northern slope, CDP sections indicate that these rocks become thinner towards the basin and may pinch out entirely. In the north and west they are regarded collectively as epicontinental platform deposits.

The Devonian to Tournaisian terrigenous sediments of the southern and eastern basin (Fig. 7) decrease steadily in thickness from the slope to the peripheral zone. In contrast, the Lower Visean deposits show increasing thickness in these directions, and probably represent deep-water deposits. In the inner zone, however, the Lower Visean strata die out and the "depression complex" gives way to thin Upper DevonianTournaisian deposits. This depression complex passes via a linear "clinoform" (deltaic slope facies - Ed.) into contemporaneous shallow-water carbonates of the northern and western slope zone.

Upper Visean to pre-Kungurian carbonate complexes form wedges passing into relatively thin deposits of the depression complex (F ig. 8). In contrast, in the northwest slope zone, shallow terrigenous Lower Visean and Vereyan (the lowest stage of the Moscovian - Ed.) complexes increase in thickness towards the basin to form reverse wedges or clinoforms, which pass into thick, deep-water layers. The extensions of these complexes to the east and south have not, however, been detected.

Upper Carboniferous to pre-Kungurian shallow-water terrigenous complexes constitute the Fore-Urals, Aktyubinsk, Ostansuk and Atzhaksin troughs. In the western flanks of the latter three, all layers decrease in thickness and in places wedge out entirely. This marks a zone of residual marginal uplift. West of this uplift, the deposits pass, via a reverse wedge, into a deep-water parallel-layered complex of infilling. Reverse wedges must also be present in the south- western and southeastern slope zones, with Artinskian deposits in the latter. The southeastern slope scarps exhibit widespread, synchronous, progradational clinoforms of the same age, which represent the delta front of a large river system.

Isolated Lower Permian clastics and salt deposits are present on the sub-salt floor. These are generally up to several hundred metres thick, but some exceed one kilometre in thickness and several tens of kilometres in length. They resemble cushions, and are believed to be widespread within the North Caspian basin, though their nature is largely unknown.

The carbonate slope scarps are partly buried under Lower Visean, Vereyan and Upper Carboniferous-Lower Permian infill complexes, which are in turn completely covered by the Kungurian salt complex. Above the latter is a sequence of shallow-water, epicontinental platform deposits.

\section{Riphean-Palaeozoic Development}

During the Riphean, there emerged within the North Caspian crystalline basement a vast deep-water depression, which persisted into the early Palaeozoic. Here accumulated a thick series of apparently deep-water terrigenous and carbonate rocks. In the northwest, the basin was adjacent to the Pachelma aulacogen of the East European Platform. A zone of Baikalian (Late Precambrian to Early Cambrian) consolidation can be delineated geophysically to the south of the Riphean-lower Palaeozoic depression.

The early Palaeozoic in the North Caspian basin must have been a long period of hiatus in sedimentation, with vast areas being uplifted and denuded. In the Devonian or slightly earlier, the northwestern and some other areas of the peripheral and inner zones were the site of an epicontinental basin in which accumulated terrigenous shallow-water sediments of medium thickness. To the south and east downwarping of the peripheral and slope zones must have led to a pericratonic trough.

In the Late Devonian, there was brief period of subsidence, which resulted in another deep basin, whose margins in places cut sharply across the outline of the Riphean-early Palaeozoic depression. Then just before the Late Visean, renewed subsidence took place, increasing the vast area of the eastern

Figure 7: Distribution of Devonian to Lower Carboniferous rocks in the North Caspian basin.

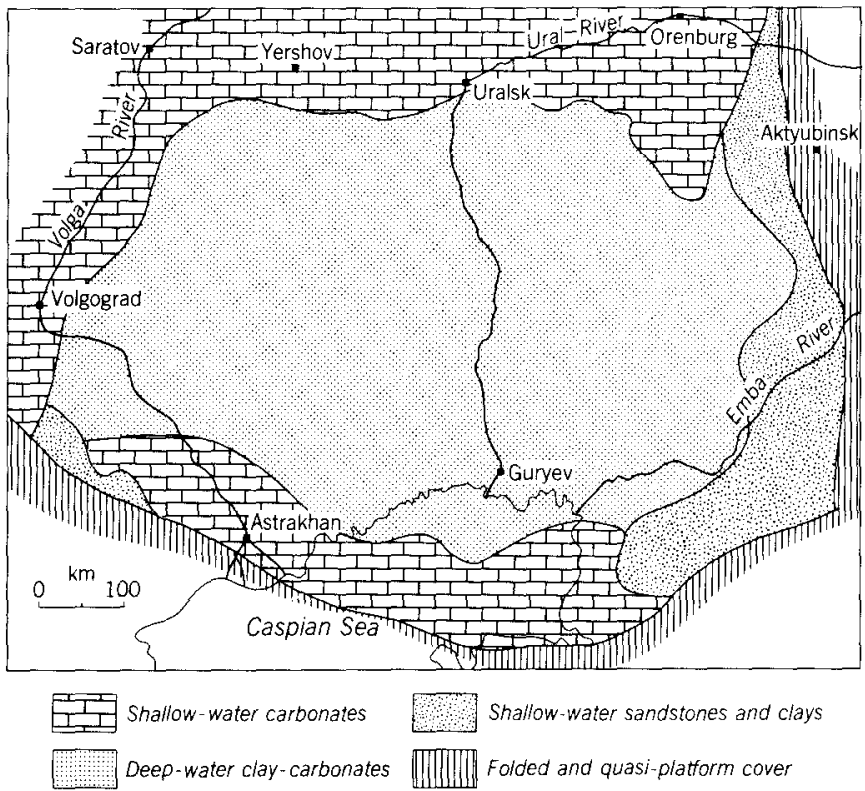


and southeastern North Caspian basin. Further midCarboniferous subsidence involved the northeastern part of the basin, advancing far to the north, parallel to the Urals. These short pulses of sinking resulted in a vast middle-late Palaeozoic basin with depths of $2 \mathrm{~km}$ or more in the inner zone. In the encircling area, syn-sedimentary subsidence (due to endogenic tectonic movements and isostasy) was compensated by epicontinental accumulation of shallowwater sediments, dominantly carbonates. When the influx of ciastics to the basin was large, the carbonates were suppressed by terrigenous sediments.

The powerful sediment source from the Ural mountains prevented the accumulation of Early Permian carbonates in the eastern slope zone and its fringes. On the continental slope of the basin, which was in fact a tectonic flexure, linear carbonate and reverse terrigenous wedges were formed, covering the original slope. Parts of the southeastern continental slope contained progradational wedges, representing the delta front of a large river that transported terrigenous clastics from eastern and southeastern sources. These wedges are related to avalanche sedimentation on relatively gentle $\left(5^{\circ}-10^{\circ}\right)$ parts of the continental slope. Progradational wedges are also absent in the pre-Artinskian sequence. The bottom of the deep-water basin was partly covered with deposits of the depression complex and the infilling complex.

The short-term sinking responsible for the deep-water basin led to a complicated evolution in the sub-salt tectonic structures of the peripheral zone of the basin. The Ripheanearly Palaeozoic basin formed the northern and western slopes of the peripheral chain of uplands, whereas the southern and eastern slopes were marked by the middle Palaeozoic pericratonic trough. The peripheral uplands were thus formed at different times - Riphean in the north and east, and middle Palaeozoic in the south and east. In the east, residual peripheral uplands shifted eastwards; this may have been responsible for the displacement of the Late Visean deep-water carbonates in part of the eastern slope zone.

The marginal uplands of the eastern basin also formed at different times. Their western flanks emerged as a result of short-term subsidences during the Late Visean to pre-Late Moscovian subsidence and the Kungurian. The eastern flanks are due to Late Carboniferous to pre-Kungurian sinking.

The 2-3 km deep basin was filled with sediments in the Kungurian when, due to tectonic movements and isostatic readjustments, the bottom of the basin subsided and up to 5 $\mathrm{km}$ or more of salt deposits accumulated. Kungurian movements were especially active in areas of pre-Kungurian subsidence, extending in some places beyond the boundaries of the deep-water basin.

From the Late Permian to Late Pliocene, a shallow platform cover accumulated with thickness controlled by movements in the underlying salt complex. At the close of the Kungurian, the movement of salt into diapiric centers caused the formation, in isolated areas, of syn-sedimentary basins in which terrigenous gypsum and anhydrite accumulated, this process continuing into the Late Permian. The flanks of these basins then subsided, converting them into "inverted" uplands "cushions" and "turtle structures" of Upper Kungurian to Upper Permian age. Some of these may be up to several tens of kilometres in area and $1 \mathrm{~km}$ or more in height.

\section{Mineral Resources}

Knowledge of the features of the Riphean to Palaeozoic strata of the basin allows us to assess its oil and gas potential and to work out a practical approach to exploitation. Artyushkov (1979) together with his colleagues (1979a, b) has proposed a model for the formation of equant deep-water basins with a wedged consolidated crust. This is based on the concept of a mantle diapir approaching the bottom of the crust, with the resulting increased temperature and pressure

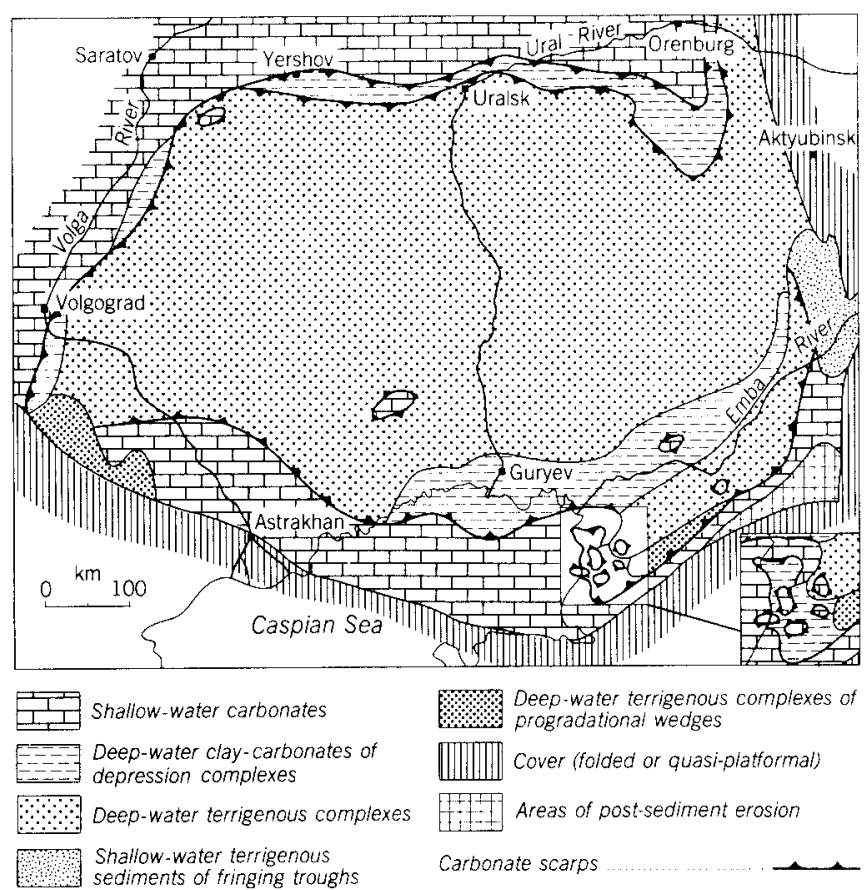

Figure 8: Distribution of Upper Visean-Artinskian rock complexes of the North Caspian basin.

extremely favourable for the extensive generation of hydrocarbons. If this model is valid, the resource potential of the North Caspian basin has been largely underestimated.

There appear to be three main targets. Of greatest interest are the middle-upper Palaeozoic carbonate deposits of the slope zone where the nearby uplands are associated with large hydrocarbon deposits. Barrier reefs that developed along the edge of the carbonate scarp should be a focus for research. Isolated reefs within the carbonate complexes are also of interest, since these are associated with hydrocarbons along the western and northern margins of the basin.

A second target is the terrigenous complexes of the Vereyan and Upper Carboniferous-Artinskian. These are dominated by lithological traps, which form reverse wedges and adjacent layers along the carbonate slope scarps. of particular interest is the Upper Carboniferous-Artinskian complex of the eastern peripheral zone. A final research target may be the widespread Upper Kungurian clastic-salt "cushion" uplifts.

\section{Summary}

A large amount of seismic and drillhole information has now been gathered on the North Caspian basin. The difference in modern views on its deep-seated structure reflects contrasts in the methods of interpreting the data. The first concept is based primarily on the use of deep drill data from the peripheral zone, to predict the structure of the inner zone on the basis of analogies with well-known parts of the East European Platform. Seismic exploration plays only a minor role in this approach, which has been used for decades to interpret the structure of epicontinental platform covers.

The second view is based on seismic data, which enables workers to establish not only the major structures but also the form and material composition of geological bodies. This seismostratigraphic approach also takes into account modern evidence of the structure and evolution of oceanic sediments. That there are gaps in stratigraphic sequences does prove, from the standpoint of seismostratigraphy and deepwater sedimentation, the existence in the geological past of upward tectonic movements and uplifts. Only through 


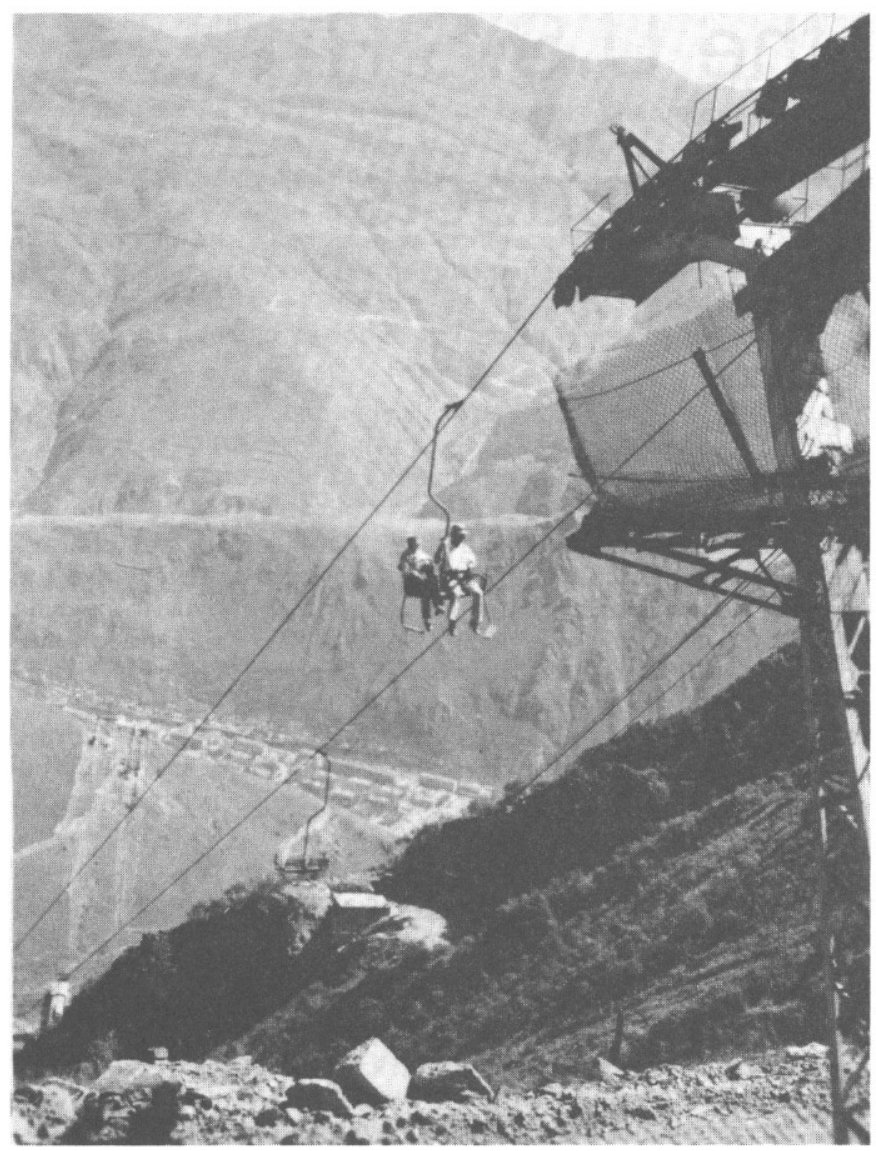

Figure 1: En route to the Tyrnyaus Mo-W-Cu skarn deposits, $150 \mathrm{~km} \mathrm{NW}$ of Ordzhonikidze in the Caucasus. (Photo by G. Leech)

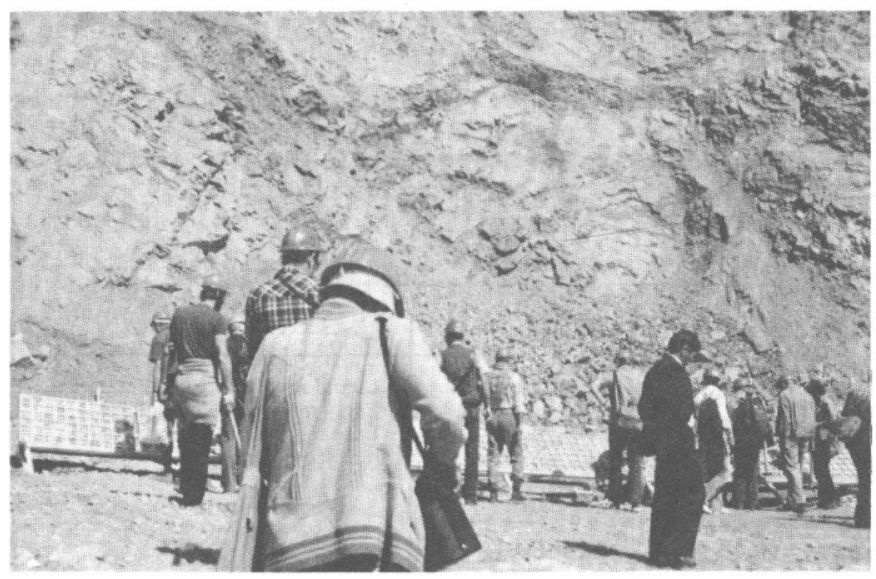

Figure 2: Participants in the 1982 IAGOD excursion examining specimens in the Mukulan ore body of the Tyrnyaus field (Photo by G. Leech)

major events in the development of endogenetic ore deposits were at $3800 \mathrm{Ma}$, when the magmatic and pyrite deposits of a basaltoid association and the metamorphogenetic pegmatites began to form, and $2500 \mathrm{Ma}$, when postmagmatic granitoid deposits first appeared. Typical representatives of the basaltoid association are magmatic deposits of chromite, titanomagnetite and $\mathrm{Cu}-\mathrm{Ni}$ sulphides, whereas granitoid complexes are characterized by postmagmatic pegmatite, albitite, greisen, skarn and hydrothermal deposits of non-ferrous, rare, noble and radioactive metals.
These ore deposits recurred later in geological time, basaltoid ores forming during phases of crustal tension and granitoid deposits during compressional cycles. The regular repetition of these pulses makes it possible to divide the history of ore formation into 10 metallogenetic epochs (Fig. 4, and see Fig. 4 of Rundquist, this issue of Episodes - Ed.). The Kolan (3800-2800 Ma) marks the onset of formation of the oldest endogenetic deposts associated with greenstone belts and granite-gneiss domes. The Belomorian (White Sea) epoch, from 2800 to $2300 \mathrm{Ma}$, ago embraces the first half of the protogeosynclinal period and corresponds to the birth of the ancient geosynclines.

The Karelian (2300-1800 Ma) marks the peak and decline of the protogeosynclinal period, and the Gothian epoch (1800$1500 \mathrm{Ma}$ ) corresponds to an intergeosynclinal period with a temporary lull in active endogenetic mineralization. A new period was then ushered in during the Grenvillian (1500-1000 Ma) when geosynclinal regimes were restored. Succeeding phases, the Baikalian (1000-600 Ma), the Caledonian (600-400 $\mathrm{Ma}$ ), the Hercynian (400-250 Ma) and the Cimmerian (250-100 $\mathrm{Ma}$ ) were distinguished by mature geosynclinal mineralization. Finally, the Alpine epoch (less than $100 \mathrm{Ma}$ ) is characterized by the cessation of geosynclinal activity leading to the development of rift tectonics controlling endogenetic ore formation.

Throughout this long history, none of the endogenetic groups experienced any pronounced qualitative changes, since magmatism recurred throughout. Basaltoid mineral associations formed from the outset of each phase or epoch to be succeeded by granitoid associations by the end. Representatives of the groups and classes of endogenetic deposits formed throughout the entire span of crustal evolution, without any appreciable change from the early to the late epochs.

\section{Environmental Regimes of Ore Formation}

Endogenetic deposits formed not only during the transformation of mobile geosynclines into stable platforms, but also in other geological environments. Four regimes can be distinguished: geosynclinal, platformal, transitional to oceanic, and oceanic. Each of these is marked by different degrees of magmatic differentiation and corresponding abundance of ore deposits, and their sequence corresponds to the series of decreasing magma-generating subcrustal systems proposed by V.V. Beloussov (1976).

The geosynclinal regime (Fig 4) is distinguished by the most complete and comprehensive magmatic differentiation from ultrabasic to ultra-acidic rocks and by the most abundant mineralization. In the U.S.S.R., the full geosynclinal cycles of the Caledonides, Hercynides, Cimmerides and Alpides are

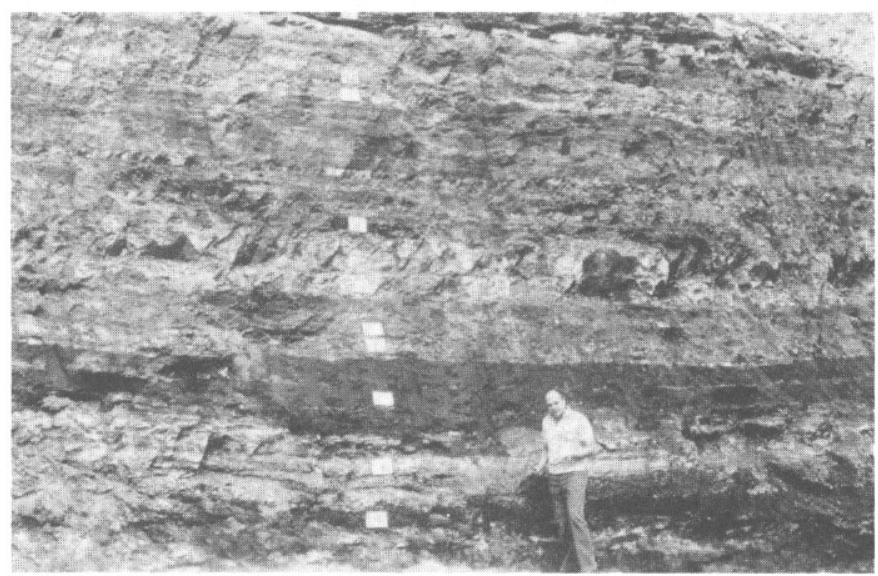

Figure 3: A close-up of the Chiatura manganese deposit of the south slope of the Caucasus about $150 \mathrm{~km}$ north of Tbilisi (Photo by G. Leech) 


\section{YOU'LL \\ SEE GEOLOGY AS YOU'VE NEVER SEEN IT BEFORE}

PLATE TECTONICS by Tasa Graphic Ants is a set of sixteen full color overhead transparencies, each with a black and white version and detailed caption. \$79.00 plus \$2.00 shipping and handling. Prices slightly higher outside the U.S. Three new sets available soon - Geologic Time, Glaciers, and Shorelines.

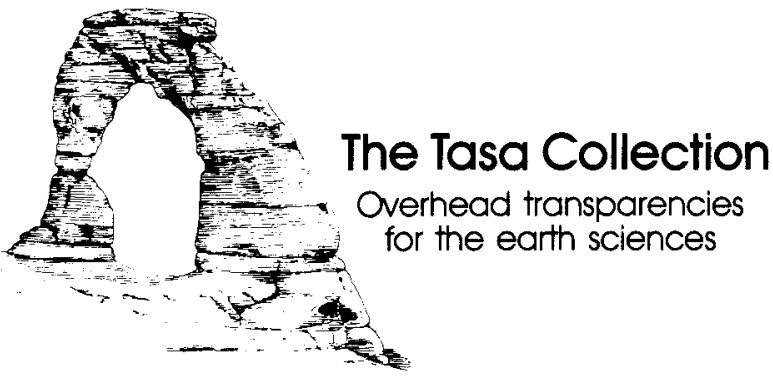

To order or receive a free catalog, write or call:

Tasa Graphic Arts, Inc., Dept. 601

P.O. Box 35053, Edina, MN 55435

(612) 835-1066 